\title{
THE EFFECT OF GOOD AGRICULTURE PRACTICES (GAP) ON SOYBEAN PRODUCTIVITY WITH COBB-DOUGLAS PRODUCTION FUNCTION ANALYSIS IN KULON PROGO REGENCY
}

\author{
Pengaruh 'Good Agriculture Practices'(GAP) Terhadap Produktivitas Kedelai \\ dengan Pendekatan Fungsi Produksi Cobb-Douglas di Kabupaten Kulon Progo
}

Fitry Purnamasari, Lestari Rahayu Waluyati, Masyhuri

Faculty of Agriculture, Universitas Gadjah Mada

St. Flora-Bulaksumur, Yogyakarta

fitrypichenk@gmail.com

Diterima tanggal : 21 Juli 2017 ; Disetujui tanggal : 17 September 2017

\begin{abstract}
This study aims to determine the level of adoption of Good Agriculture Practices (GAP) and the influence of GAP and other factors of production on soybean productivity. The number of respondents in this research was 50 farmers taken by random sampling. This research used proportional parameter test and multiple linear regression analysis with Ordinary Least Square (OLS) method. This research has been declared valid, reliability, data have been the normal distribution, free from multicollinearity and heteroscedasticity problem. The result of the analysis shows that (1) the adoption rate of GAP of soybean farmers in Kulon Progo Regency is categorized as a high category. Farmers adopted $83,07 \%$ of the overall GAP portion of input, land preparation, planting, fertilizing, crop protection, irrigation, harvesting, and post-harvest. (2) The result of the $\mathrm{R}^{2}$ test shows that $47,8 \%$ variation of soybean productivity can be explained by the eight independent variables and the remaining is explained by variables outside the model. $F$ test results show that the independent variables together affect the productivity of soybeans. The result of $t$ test shows that Seed, manure, Gandasil fertilizer, GAP adoption rate significantly positive and NPK fertilizer significantly negatively affect soybean productivity.
\end{abstract}

Keywords : Cobb-Dauglas, GAP, Productivity, Soybean

\section{INTISARI}

Penelitian ini bertujuan untuk mengetahui tingkat adopsi Good Agriculture Practices $(G A P)$ serta pengaruh GAP dan faktor produksi lainnya terhadap produktivitas kedelai. Jumlah responden dalam peneltian ini sebanyak 50 orang petani yang diambil secara acak. Penelitian ini menggunakan pengujian parameter proporsional dan analisis regresi linear berganda dengan metode Ordinary Least Square (OLS). Penelitian ini telah dinyatakan valid, reliable, telah berdistribusi normal, bebas dari masalah multikolinearitas dan heteroskedastisitas, sehingga dapat dilakukan analisis regresi linear berganda. Hasil analisis menunjukkan bahwa (1) tingkat adopsi GAP petani kedelai di Kabupaten Kulon Progo tergolong dalam ketegori tinggi. Petani mengadopsi sebesar 83,07\% dari keseluruhan bagian GAP yaitu input, persiapan lahan, penanaman, pemupukan, perlindungan tanaman, pengairan, panen dan pascapanen. (2) Hasil uji R2 
menunjukkan bahwa 47,8\% variasi produktivitas kedelai dapat dijelaskan oleh kedelapan variabel independen dan sisanya dijelaskan oleh variabel diluar model. Hasil Uji F menunjukkan bahwa variabel independen secara bersama-sama berpengaruh terhadap produktivitas kedelai. Hasil Uji t menunjukkan bahwa benih, pupuk kandang, pupuk Gandasil, tingkat adopsi GAP secara signifikan berpengaruh positif dan pupuk NPK secara signifikan berpengaruh negatif terhadap produktivitas kedelai.

Kata Kunci : Cobb-Dauglas, GAP, Kedelai, Produktivitas

\section{INTRODUCTION}

Soybean which the latin name is Glycine max (soybean yellow); Glycinesoja (black soybean) is a versatile plant. One of the important food commodities for Indonesia after rice plant and maize is soy. The average demand for soybean in Indonesia annually is \pm 2.2 million tons of dry seeds. Meanwhile, according to BPS data in 2015 showed that production only reached 963,099 tons, while the rest is imported from other countries.

Indonesia's soybean production centers located in seven (7) provinces, contributing $84 \%$ of national soybean production in 2015 , and 27 other provinces contributing $16 \%$. The largest contribution was given by Province of East Java at $33.89 \%$ (production number is 208,067 tons), followed by West Nusa Tenggara $15.47 \%$ (production number is 94,948 tons), and Central Java $11.51 \%$ (production number is 70,629 tons). Four other central provinces contributing under $10 \%$, that is West Java with the number is $9.8 \%$ (production number is 60,172 tons), Aceh 5.34\% (average production is 32,796 tons), South Sulawesi $6.20 \%$ (average production is 38,036 tons), and DI Yogyakarta $2.26 \%$ (average production is 13,886 tons) (Badan Pusat Statistik, 2016). Kulon Progo Regency is one of the soyproducing districts in Yogyakarta besides Gunungkidul and Sleman. Soybean crop is used as a crop after rice plant. Soybean production is still low.

Low soybean production is caused by several things, which are: (1) lack of land allocation definitively and specifically intended for soybean production systems; (2) high risk farming of soybean, low productivity and low income of soybean farming; (3) the subject of soybean farming is a traditional farmer with a small scale; (4) the adoption of production technology is slow; and (5) the data of harvested area is less accurate, often biased and soybean production enhancement program is not focused on the expansion of new areas (Sumarno and Adie, 2010).

According to Alimmoeso (2008), quoted by Zakaria (2010) suggested that the increase in soybean production could be done with the expansion of planted area, 
the increasing in productivity, production security and institutional strengthening.

A good guidelines for the cultivation of food crops/ Good Agriculture Practices (GAP) was published as a guideline in carrying out the cultivation of food crops correctly and properly, with the expectation it will be obtain a high productivity, good product quality, maximum profitability, environmental friendliness and attention to security aspects, health and welfare of farmers and sustainable production efforts. The legal basis of GAP in Indonesia for food crops regulated in Ministry of Agriculture Regulations Number 48/ Permentan/ OT.140/ 10/2006.

Setiawan et al (2015) in his research about GAP (Good Agriculture Practice) implementation of pepper and the effect on pepper productivity has significant influence accumulatively. Bayramoglu, et al(2010) EurepGAP certified tomato producers gained higher output and gained 2.8 times more net profit than non-certified EurepGAP.

Soybean productivity also affected by other factors of production besides GAP. Production factors is known as the term inputs, production factors and production sacrifice. Production factors determinethe size of production, whether it is big or small. In various experiences indicate that the land as production factors, the capital to buy seeds, fertilizer, medicine, labor and management aspects are the most important production factors. The relationship between production factors (input) and production (output) is usually called as production function or referred to the relationship factor (Isnowati, 2014).

Soekartawi (1990), quoted by Rahayu (2010) states that the use of production factors such as land, labor, capital (fertilizers, seeds and medicines) plays an important role in farming activity. In agricultural development, inaccuracy of number and combination for production factors produce a low production result or high cost of production which makes farmer income is low.

The purpose of this study is to determine the level of GAP adoption on soybean commodity in Kulon Progo Regency and the effect of GAP and soybean production factors on productivity.

\section{METHODS}

This research used secondary and primary data to get the data. Secondary data was a data obtained from literature and a reference document from related institutions. Primary data obtained directly from farmers used a questionnaire by interview. The number of respondents in this research was 50 farmers taken by random sampling. An instrument that was given to the farmer respondents should be analyze its validity and reliability in advance used SPSS 16.0, so the data will valid and reliable. A measuring 
instrument was said to have good validity if it can measure accordingly. Validity (questionnaire) was calculated with the formula fromproduct moment correlation (Pearsons correlation) as follows:

$r_{x y}=\frac{n\left(\sum X Y\right)-\left(\sum X\right)\left(\sum Y\right)}{\sqrt{\left[n\left(\sum X^{2}\right)-\left(\sum X\right)^{2} \mid n\left(\sum Y^{2}\right)-\left(\sum Y\right)^{2}\right]}}$

Description:

$\mathrm{r} x y=$ coefficient of correlation per item

$\mathrm{N}=$ Number of respondents

$\mathrm{X}=$ Score $\mathrm{per}$ item $/$ items

$\mathrm{Y}=$ Total Score

Product Moment Correlation then compare correlation number with critique numbers from table correlation $r$ which is its value should be at certain degree (5\%). If the correlation number is greater than the figures in the table $r=0.632$, then the item is declared as valid question.

Reliability test is the consistency of a measuring instrument that shows the extent to which the measuring instrument is trustworthy or reliable when used repeatedly. To measure the reliability of research instrument, it will be carried out statistical tests Cronbach's Alpha. The suggested value ofCronbach's Alphais $\geq$ 0.6 .

Likert scale is used to measure the adoption level of GAP, then it use parameter proportion test as follows.

$z=\frac{P-P_{0}}{\sqrt{\frac{P_{0}\left(1-P_{0}\right)}{n}}}$
Description:

$\mathrm{P} \quad=$ Percentage of adoption rate of observations

P0 = Percentage of adoption rate (at 0.50 )

$\mathrm{N}=$ Number of Samples

To determine the factors that affect the soybean productivity in Kulon Progo Regency it can use the multiple regression analysis with Ordinary Least Square method (OLS). The model use the equation of Cobb-Douglas function as follows:

Ln $Y_{q}=\ln \alpha+b_{1} \ln x_{1}+b_{2} \ln x_{2}+b_{3} \ln x_{3}+$ $\mathrm{b}_{4} \ln \mathrm{x}_{4}+\mathrm{b}_{5} \ln \mathrm{x}_{5}+\mathrm{b}_{6} \ln \mathrm{x}_{6}+\mathrm{b}_{7} \ln \mathrm{x}_{7}+$ $\mathrm{b}_{8} \ln \mathrm{x}_{8}+\mu$

Description:

$\mathrm{YQ}=$ Soybean Productivity $(\mathrm{Kg} / \mathrm{Ha})$

a $=$ value of the constant

$\mathrm{b}_{1} \mathrm{~b}_{2}, \mathrm{~b}_{3,} \mathrm{~b}_{4,} \mathrm{~b}_{5}=$ regression coefficient

$\mathrm{x}_{1}=$ Land (Ha)

$\mathrm{x}_{2}=$ Seeds $(\mathrm{kg} / \mathrm{Ha})$

$\mathrm{x}_{3}=$ NPK Fertilizer $(\mathrm{kg} / \mathrm{Ha})$

$\mathrm{x}_{4} \quad=$ Manure $(\mathrm{kg} / \mathrm{Ha})$

$\mathrm{x}_{5}=$ Gandasil Fertilizer (gram/ha)

$\mathrm{x}_{6} \quad=$ Pesticides (liters $/$ ha)

$\mathrm{x}_{7}=$ Labor $(\mathrm{HOK} / \mathrm{ha})$

$\mathrm{x}_{8}=$ GAP Adoption Rate (score)

$\mu \quad=$ mistake factor

\section{Classical Assumption Test}

To get a good model or qualifiy for multiple linear regression, model analysis with classical assumption (normality test, 
multicollinearity and heterocedasticity) should be done.

Normality test analyze use the Jarque-Bera (JB). This test was based on the coefficient of kurtosis (kurtosis and coefficient slope or skewness). The formula Jarque Bera as follows.

$$
I B=\frac{n}{6}\left(S^{2}+\frac{(K-3)^{2}}{4}\right)
$$

The formula above contain $\mathrm{n}$ as sample size, $\mathrm{S}$ describesthe slope and $\mathrm{K}$ expresses the wedge. This test compared the statistics Jarque-Bera (JB) with a value from Table. If the value of Jarque-Bera $(\mathrm{JB}) \leq$ Table then the residual value has normal distribution.

Multicollinearity is a condition which hasliniear relationship between independent variables. Multicollinearity can be seen from the value of tolerance and the opponent of Variance Inflation Factor (VIF). If the value of tolerance $\leq 0,10$ or $\mathrm{VIF} \geq 10$, then there is a multicollinearity and otherwise (Ghozali, 2012).

Heterocedasticity test conducted to determine whether there is the same distribution of the residual variance. If the probability values in Obs*R-Squared $>$ critical value $(\alpha)$, then $\mathrm{H}_{0}$ is accepted, it means there is no heterocedasiticity and otherwise.

\section{Statistic Test}

Statistic test includes testing the coefficient of determination $\left(\mathrm{R}^{2}\right), \mathrm{F}$ test and $\mathrm{t}$ test. The coefficient of determination $\left(\mathrm{R}^{2}\right)$ describes how much percentage of the total variation in the dependent variable could be explained by the model, the greater the $\mathrm{R}^{2}$ the greater influence in explaining the dependent variable models. $\mathrm{R}^{2}$ values has range from 0 to 1 , an $R^{2}$ of 1 means there is a perfect match, while the value 0 indicates no relationship between the dependent variable with the variables explained. Therefore, the value of $\mathrm{R}^{2}$ which is close to 1 , means the closer of its model's ability to explain the dependent variable, and otherwise.

F statistic test determine the effect of simultaneous independent variable on dependent variable whether it is significant or not. The t-test is used to determine the effect of independent variable partially towards dependent variable.

\section{RESULTS AND DISCUSSION}

\section{Adoption Level of Good Agriculture Practices (GAP)}

In this study, GAP is divided into inputs, land preparation, planting, fertilization, plant protection, irrigation, harvest and post-harvest. Validity test using product moment correlation coefficient of Karl Person indicates that the instrument is valid with r-count value is greater than the value of r-table Product Value Critical Moment $(0.2306)$ at the $5 \%$ significance level. Reliability testuse Alpha $(\alpha)$ of Cronbach which show that the value of Cronbach's Alpha is greater than 0.6, 
it means the variables are reliable and consistent (reliable).

Respondents were grouped into three categories, they are low, moderate and high of adoption level based on total score in each scope. The number of items which were used to measure the level of adoption of GAP has 57 statement divided into 7 scope. Each statement is adjusted to the Regulation of the Minister of Agriculture Number 48/ Permentan/ OT.140/ 10/2006 about thegood guidelines for cultivation of food crops.
The Table 2 shows that the average score for input is $2.65(88.53 \%)$ means that farmers are adopting about $88.53 \%$ of the overall input. The average score of land preparation is $2.46(81.52 \%)$, planting is $2.08(69.33 \%)$, fertilizing is $2.43(80.91 \%)$, plant protection is $2.45(81.61 \%)$, irrigation is $2.66(88.66 \%)$, harvest and post harvest are $2.78(92.66 \%)$. While the total adoption of GAP had an average score of 2.49 $(83.07 \%)$ and classify as high category. Farmers distributiontowards the rate of GAP adoption can be seen in Table 3 below.

Table 1.The Rate of GAP Adoption for Soybean in Kulon Progo Regency

\begin{tabular}{clcc}
\hline No. & \multicolumn{1}{c}{ Scope of Adoption } & Average Score & Percentage $(\%)$ \\
\hline 1. & Input & 2.65 & 88.53 \\
2. & Land Preparation & 2.46 & 81.52 \\
3. & Planting & 2.08 & 69.33 \\
4. & Fertilization & 2.43 & 80.91 \\
5. & Plant protection & 2.45 & 81.61 \\
6. & Irrigation & 2.66 & 88.66 \\
7. & Harvest and Post Harvest & 2.78 & 92.66 \\
\hline Total & & 2.49 & 83.07 \\
\hline
\end{tabular}

Source: Primary Data Analysis, 2017

Table 2. Distribution of Soybean Farmers to Adopt GAP

\begin{tabular}{lcccccc}
\hline & \multicolumn{5}{c}{ Category adoption Levels } \\
\cline { 2 - 7 } \multicolumn{1}{c}{ Scope Adoption } & \multicolumn{2}{c}{ Low } & \multicolumn{2}{c}{ Moderate } & \multicolumn{2}{c}{ High } \\
\cline { 2 - 7 } & Frequency & $\begin{array}{c}\text { Person } \\
(\%)\end{array}$ & Frequency & $\begin{array}{c}\text { Person } \\
(\%)\end{array}$ & Frequency & $\begin{array}{c}\text { Person } \\
(\%)\end{array}$ \\
\hline Input & 1 & 2 & 4 & 8 & 45 & 90 \\
Land Preparation & 3 & 6 & 11 & 22 & 36 & 72 \\
Planting & 12 & 24 & 19 & 38 & 19 & 38 \\
Fertilization & 4 & 8 & 8 & 16 & 38 & 76 \\
Plant Protection & 3 & 6 & 10 & 20 & 37 & 74 \\
Irrigation & 3 & 6 & 6 & 12 & 41 & 82 \\
Harvest and & 1 & 2 & 6 & 12 & 43 & 86 \\
Postharvest & 0 & 0 & 13 & 26 & 37 & 74 \\
\hline Total Level Adoption & & & & & & 26 \\
of GAP & & &
\end{tabular}

Source: Primary Data Analysis, 2017 
Table 3. Analysis Result of GAP Adoption Rate for Soybean

\begin{tabular}{clrrrc}
\hline No. & ScopeAdoption & $\mathbf{Z}_{\text {Calculate }}$ & $\mathbf{Z}_{\text {Table }}$ & Conclusion & Criteria \\
\hline 1. & Input & 5.657 & 1.645 Ho rejected & High \\
2. & Land Preparation & 3.111 & 1.645 Ho rejected & High \\
3. & Planting & -1.697 & 1.645 Ho received & Average \\
4. & Fertilization & 3.677 & 1.645 Ho denied & High \\
5. & Plant Protection & 3.394 & 1.645 Ho rejected & High \\
6. & Irrigation & 4.525 & 1.645 Ho rejected & High \\
7. & Harvest and Postharvest & 5.091 & 1.645 Ho rejected & High \\
\hline Total Adoption of GAP & 3.394 & 1.645 Ho rejected & High \\
\hline
\end{tabular}

Source: Primary Data Analysis, 2017

The adoption rate is measured using the likert scale of 1 (low), 2 (medium) and 3 (high). Number of statements each is input 10, land preparation 11, planting 5 , fertilization 11 , plant protection 12 , irrigation, harvest and post harvest 5 statement. Categorization is done by subtracting the highest score with the lowest score then divided into three representing each category. Farmers will be categorized according to the number of scores obtained in each scope.

Table 2 above show the total value of GAP for all its scope, most farmer respondents are at high category with 37 people or $74 \%$. While others in moderate category have 13 people or $26 \%$ and no farmer who is in low category of GAP adoption.

To analyze the hypothesis about GAP adoption level in Kulon Progo Regency, it should analyze the proportion parameter $\mathrm{Z}$ with a significance level of 0.05 . The analysis result of GAP adoption rate for soybean in Kulon Progo Regency can be seen in Table 3.
Table 3 show that among 7 scope of GAP, the others 6 which are inputs, land preparation, fertilization, crop protection, irrigation, harvesting and post harvest have a high adoption rate. While the scope of the planting is in moderate category.

\section{Input}

Supply input was important in soybean cultivation. The inputs in this research are seed, labor, and equipment used by the farmers. GAP adoption achievement levels for the input component are presented in Table 2. In Table 1 shows that the percentage of soybean input usage is $88.53 \%$ of all assessment aspect. In Table 2 , most farmerswas included in the high category $(90 \%)$, moderate $(8 \%)$ and low $(2 \%)$. This is compatible with the statistical test using parameter proportion analysis stating that $\mathrm{H} 0$ is declined because of $\mathrm{Z}$ score (5.657) $>Z$ table (1.645) which means that the rate of soybean GAP adoptionis mostly in the high category.

The most seeds varieties are used by farmers is $92 \%$ for Grobogan and $8 \%$ 
for Merapi. Seed pricefor Grobogan is Rp. 6,000-15,000 and for Merapi is Rp. 14,000 . Some farmers use seeds from government and input store around their residence. Farmers respondents use about $75.46 \mathrm{~kg} / \mathrm{ha}$. The suggestion to use quality seed with the power to grow $>85 \%$, healthy and clean with the total seed requirement between $40-60 \mathrm{~kg} / \mathrm{ha}$, depending on seed size, the greater of the seedsize, the more seeds were used (Direktorat Jenderal Tanaman Pangan, 2015).Labor value in soybean cultivation in Kulon Progo is 93.52 HOK/ Ha. The labor comes from their own family and outside of the family. The wages paid for labor is Rp. 30,000 - Rp. $70,000 /$ person/ day. This labor is used in the process of land preparation, planting, fertilization, plant protection, irrigation and harvest and postharvest.

Agricultural tools is the input to facilitate the farmers in soybean cultivation. The tools are hoes, water spray, sickle, and thresher. Hoe is used in land preparation and cultivation process as a tool for weeding, sickle is to crop the stem of soybean in harvesting and water sprayto help fertilization and pesticide usage. The thresher is toseparate betweenshell and soybean seeds. Some farmers usethresher and some of them use manual method.

\section{Land preparation}

Land preparation is the part of soybean cultivation. Land preparation is the first step in soybean cultivation process. The average of farmers' land area is 0.23 hectares. Table 1 shows that the average of GAP implementation for land preparation section only at $81.52 \%$. The adoption level of GAP for soybean classified in the high category (72\%), moderate (22\%), and low (6\%). Test results hypothesis in Table 3 states that $\mathrm{H}_{0}$ rejected because of $\mathrm{Z}$ score (3.111) $>$ Ztable (1.645) means that the rate of GAP adoption for soybenmostly is in the high category.

In Kulon Progo, generally farmers plant soybeans in land which is used to plant a rice. According to the rules of the local government, farmers are encouraged to make a crop rotation with the pattern of rice plant-rice plant-soybeans. Farmers usually plant soybean in the field which is used to planted rice plants becauseit is difficultfor the farmers to cultivate a new land considering the time and efficiency. However, the canal for drainage is still needed todispose excess water or to equalize the amount of water. In addition, land preparation is also done by using rice straw as mulch replacement which over laid evenly on the surface of the land. To increase the soil fertility, farmers also add compost in rice fields which will be planted a soybean.

\section{Planting}

Planting is done after land preparation. Table 1 shows that farmers 
only apply approximately $69.33 \%$ of GAP's component of cultivation. Generally, farmers are not doing processing. Farmer planta rice plant directlyin land that has been used for rice plant. Distribution of farmers on the adoption rate of GAP in the cultivation showed that $38 \%$ of farmers includein higher categories, the moderate category also having the same percentage, while for lower category has $24 \%$. The statistical result based on calculation of parameter proportion in Table 5.9 shows that $\mathrm{Ho}$ is accepted because $\mathrm{Z}$ score $(-1.697)<$ Ztable $(1.645)$ means that the rate of GAP-SOP adoption for soybeans mostly include in the moderate category.

Farmers included in the low and moderate category because some farmers do not follow the recommended planting distance of 40x15 cm and 40x10 cm, they only follow the distance of rice planting without any land processing. In addition, some farmers use seeds from previous products instead of seeds that are certified or labeled.

Soybean planting in Kulon Progo 2016 was conducted in May-June. The planting schedule is set up by local government in order not to disrupt the schedule of the next cropping season. Generally farmers plant for two days after harvesting. The farmers make a hole in the ground following the range which is used to madefor rice plant. Each hole was given two soybean seed. After that, the plant is covered with rice straw to keep moisture and avoid the pests.

\section{Fertilization}

Table 1 shows that the average of farmer only adopt GAP for fertilization component of $80.91 \%$. Farmers in the category is included of High (76\%), Moderate (16\%) and Low (8\%) category. The statistical analysisuse proportional parameters test in Table 5.9, states that $\mathrm{H} 0$ is declined because $\mathrm{Z}$ score (3.677)> $\mathrm{Z}$ table (1.645) means that the rate of GAP adoption for soybean tegolong mostly in the high category.

Farmers are included in the moderate category because some farmers do not routinely use organic fertilizer and still prioritize the use of inorganic fertilizer. Fertilization is to increase the fertility of the soil so that soybean will grow well. Manure is given before planting the crop, at flowering stage when NPK fertilizer was given, and when Gandasil was given. Gandasil is a foliar fertilizer, which is given to the plant by dissolved in water and sprayed evenly on the twigs and leaves. There are two kinds of Gandasilwhich is used by farmers, they are Gandasil D for leaves, it is used when soybeans is in growing and recovery stage. The other kind of Gandisil is Gandasil $B$ which is used in generative phase, the meaning of Gandasil B is a fruit. Gandasil $\mathrm{B}$ is used to support the formation of flower buds and form carbohydrates in the fruit. The 
average use of NPK fertilizer is $107.91 \mathrm{~kg} /$ ha, compost is $2637.74 \mathrm{~kg} / \mathrm{ha}$ and Gandasil is $15.19 \mathrm{pack} / \mathrm{ha}$ (100gr/ pack).

\section{Plant Protection}

Most of the farmers have been applying GAP for plants protection componentwhich is $81.61 \%$ (Table 1 ). Farmers distributiontowardsadoption rate of crop protection according to Table 2 is in high category $74 \%$, while $20 \%$ is for moderate category and $6 \%$ is for low category. This is consistent with statistic test results in Table 4 which indicates that $\mathrm{H} 0$ is rejectedbecause $Z$ score (3.394) $>$ Ztable (1.645), it means that the adoption rate of GAP for soybeanis mostly in the high category.

Assessment indicators for fertilization include the use of inorganic fertilizers listed or recommended by the government, the use of organic fertilizers derived from plants or animals, the use of appropriate fertilizer quality, time, dose and mode of application, prioritizing the use of organic fertilizers rather than inorganic, spraying fertilizer done without leaving Residue and does not cause pollution and keep the fertilizer in a clean, safe and closed place. Farmers included in the moderate category means that farmers do not routinely carry out plant protection in accordance with assessment indicators.

Crop protection made by farmers is to control pest and disease. Spraying is done only when there are pests to avoid the risk of crop. Spraying usually only done once in a season. To prevent the growth of weeds, farmers use rice straw to cover the seed in land preparation and planting process. Kind of pesticides which is used include Bassa, Darmabas, Fastac, Extragen, Lannate, and Marshal.

\section{Irrigation}

GAP for watering component have been adopted by $88.66 \%$ according to Table 1. Farmers distribution towards GAP adoptionis in high category (82\%), moderate (12\%) and low (6\%). While the statistical test results in Table 3 concluded that $\mathrm{H} 0$ is rejectedbecause $\mathrm{Z}$ score (4.525)> Ztable (1.645) means that the rate of GAP adoption of soybean for irrigation part is included in high category.

Soybean is a plant which is tolerant of dry conditions. However, soybeans require water during the growth period. Four stages of phase on soybean plants that require water is in early growth phase, during flowering, pod formation and seed filling (Adisrwanto, 2008).

\section{Harvest and Post-harvest}

GAP adoption rate of harvest and post-harvest has been adopted by farmers with the amount of $92.66 \%$. Farmers who belong to the high category by $86 \%$, while moderate category is $12 \%$ and low category is $2 \%$. It can be said that most farmers is in high category. This is according to the results of statistical tests using the proportional 
parameter which concluded that $\mathrm{H} 0$ is rejected because $\mathrm{Z}$ score (5.091) $>\mathrm{Z}$ table (1.645). It means that the level of GAP adoptionfor harvest and post-harvest soybean crop largely classified in the high category.

Soybean plants which are ready to be harvested is marked by falling leaves (the amount of leaves in the crops are about $5-10 \%$ ) and $95 \%$ yellow pods are yellow. Generally, for Grobogan varieties are harvested in less than 80 days. Harvesting is done by cutting the stem using a sickle. To threshing, the farmer use the Power Treser (threshing machine) and some of them use manual method with a wooden bat. Afterwards, the beans are cleaned and drying for 2-3 days until the moisture content of $10-12 \%$ and packed in plastic bags that can last a long time and are not attacked by pests and diseases.

\section{Factors that affect Soybean Productivity Classical Assumption Test}

Classical assumption test such as normality test, multicolinearity and heteroskedasticity done to get a good model or qualify multiple linear regresi before analyze with analysis tools Eviews 9.0. Normality Test Results indicate that the Jarque-Bera value is 0.737 with probability $0.609>0.05$ ( $95 \%$ confidence level) which means that the residual distribute normally.

The analysis of multicolliniearityis used to determine whether an independent variable in the regression equation is not correlated with seeing the value of tolerance and the value of Variance Inflation Factor (VIF).

Table 4 shows that the all of the variables that influence soybean yield has a value of VIF is less than 10, so it can be concluded that the regression model is good because there is no correlation between independent variables problem or Multicollinearity. Heteroskedasticity test is to determine whether there is the same distribution of the residual variance through the analysis of White Heteroscedastisticity.

Table 4. Test Results of Multicollinearity

\begin{tabular}{|c|c|c|}
\hline No. & Variable & Value VIF \\
\hline 1. & Land (X1) & 4.048 \\
\hline 2. & Seeds (X2) & 1.642 \\
\hline 3. & NPK Fertilizer (X3) & 1.843 \\
\hline 4. & Manure (X4) & 1.729 \\
\hline 5. & Gandasil Fertilizer (X5) & 1.908 \\
\hline 6. & Pesticides (X6) & 1.710 \\
\hline 7. & Labor (X7) & 3.984 \\
\hline 8. & GAP Adoption rate (X8) & 1.384 \\
\hline
\end{tabular}

Source: Primary Data Analysis, 2017 
Table 5 show that the value of Prob. linear regression analysis to determine the Chi-Squared at $\mathrm{Obs}^{*} \mathrm{R}$ Squared is 0.074 , factors that affect the soybean productivity greater than 0.1 , it means the regression in Kulon Progo model is homokedasticity or in other words there is no problem assuming non heterokedasticity so it can be concluded that the data for each independent variables in the model have a homogeneous variance.

The result of classic assumption test shows that the data was normally distributed, free of problems for multicollinearity and heteroscedasticity, so it can do a multiple

\section{Statistical Test}

Hypothesis testing for factors that affect the soybean productivity using multiple linear regression analysis to analyze the coefficient of determination $\left(\mathrm{R}^{2}\right), \mathrm{T}$ test and test F. Significance level used in this study is $95 \%$ and $90 \%(\alpha=$ $5 \%, \alpha=10 \%)$.

Table 5. Test Results of Heterokedasticity

\begin{tabular}{llll}
\hline F-statistic & 2.055 & Prob. F & 0.063 \\
Obs * R-Squared & 14.310 & Prob. Chi-Square & 0.074 \\
\hline
\end{tabular}

Source: Primary Data Analysis, 2017

Table 6. Test Results t Factors Affecting Soybean Productivity

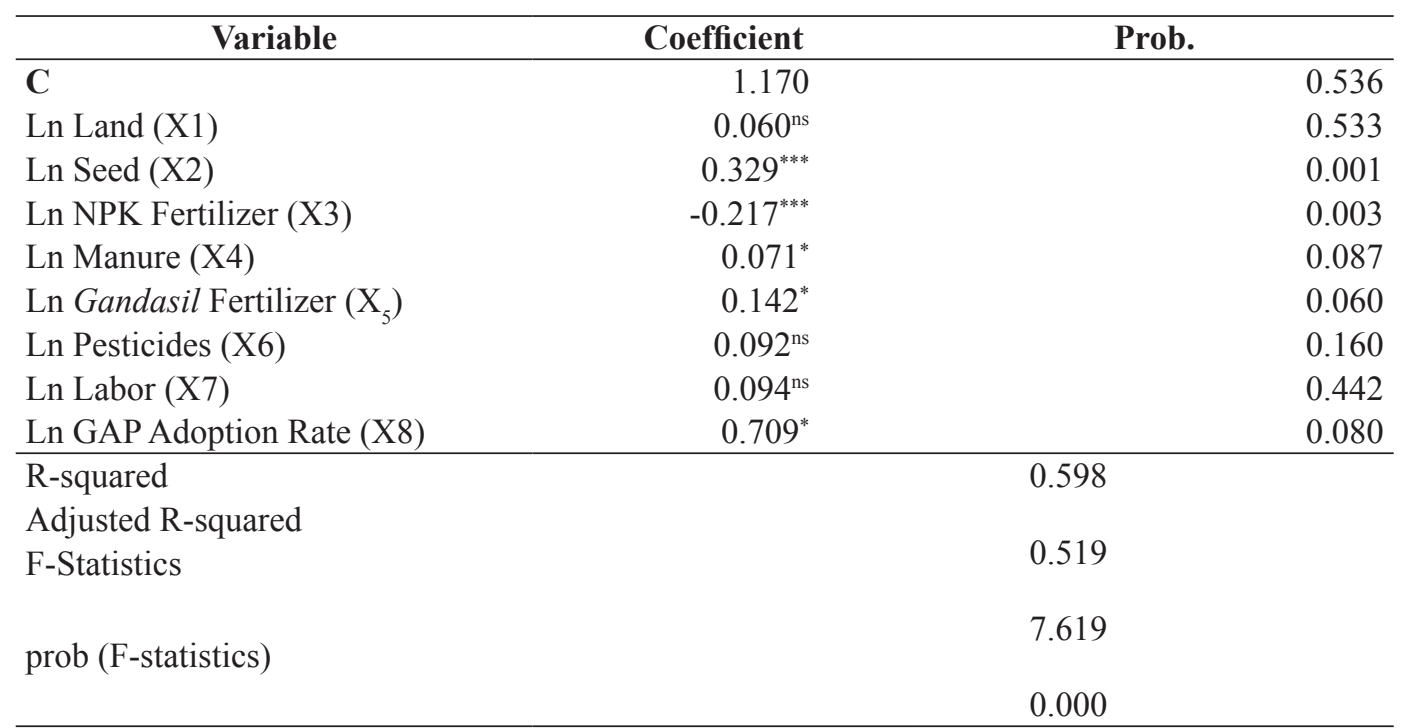

Source: Primary Data Analysis, 2017

Description:

$* * *$ = significance level $99 \%$

* = significance level $90 \%$

ns $=$ non-significant 
Table 6. shows that the result ofAdjusted R-Square dis 0.519, which means $51.9 \%$ of the variation of soybean productivity can be explained by the eight independent variables, they are land, seeds, NPK Fertilizer, manure, Gandasil Fertilizer, pesticides, labor and GAP adoption rate. The remaining valueis $48.1 \%$ explained by variables outside the model.

$F$ test results in Table 6 indicate that the independent variable land, seeds, NPK Fertilizer, manure, Gandasil Fertilizer, pesticides, labor and GAP adoption rate influence towards soybean productivity jointlywith the F-statistic equal to 7.619 , with a probability value $<\alpha=1 \%$ is 0.000 .

T-test is used to determine the effect of each independent variables towards dependent variable. The significance level which is used in this study is $99 \%$ and $90 \%$ $(\alpha=1 \%, \alpha=10 \%)$. Mathematically, Table 6 shows the regressionmodel between soybean productivity with influential variable factors written in the following equation.

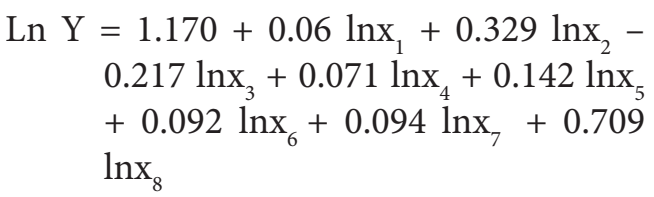

\section{Land $\left(X_{1}\right)$}

Table 6 shows that the land areais not significantly at $99 \%$ confidence level and $90 \%$ because of $p$-value score of land area is 0.533 larger than $\alpha(0,1)$ means that any increase in the number of Land is not significantly would reduce soybean productivity.

\section{Seeds $\left(X_{2}\right)$}

The result of T-test in Table 6 indicate that the seeds is significantly influence towards soybean yield at $99 \%$ significance level with p-value of 0.001 is smaller than $\alpha(0.01)$. Regression coefficient value is 0.329 has positive effect, it means that the increase of seeds number by 1 percent would increase soybean yield at 0.329 percent, assuming other factors remain (constant). Seed is one of the important production factor in soybean. Quality seeds is one of the factors that determine the soybean productivity. This is in line with research Isnowati (2014), Tahir (2011), Mahabirama (2013).

\section{NPK Fertilizer $\left(X_{3}\right)$}

Phonska or NPK Fertilizer is a fertilizer that contains many essential nutrients that plants need such as nitrogen $(\mathrm{N})$, phosphorus $(\mathrm{P})$, potassium $(\mathrm{K})$ and sulfur (S). T-test results in Table 6 shows that NPK fertilizer significantly influence towards soybean productivityat significance level of $99 \%$ with p-value is 0.003 , smaller than $\alpha(0.01)$. Regression coefficient value is negative with score -0.217 , it means that any increase in the number of NPK by 1 percent would reduce soybean productivity 
for $0.217 \%$, assuming other factors remain (constant).

The maximum dose of NPK is 200 $\mathrm{kg} / \mathrm{ha}$ which is applied 2 times, $100 \mathrm{~kg}$ of basic fertilizer is given at the time of planting and $100 \mathrm{~kg}$ of fertilizer is given 20 days after planting. The average of NPK fertilizer used by farmer is 105.91 $\mathrm{kg} / \mathrm{ha}$. The addition of NPK fertilizer would reduce soybean productivityif it has reached maximum usage. This is according to research by Ernawanto (2012) which states that plant height affected by NPK fertilization/ Phonska at the age of 30 days or 60 days, but the addition of fertilizer above $100 \mathrm{~kg} /$ ha had no significant to height. It is the same with NPK/ Phonska fertilizer that can increase soybean seeds production but the addition of fertilizer above $75 \mathrm{~kg}$ / ha will not show difference towards productivity. Fertilizer will increase of productivity if the fertilizer is already proper for its variety, dose, time, and the way of fertilization.

\section{Manure $\left(X_{4}\right)$}

Manure is one of organic fertilizer which is good for plants. The result of statistic test show that manure affect significantly towards soybean productivity for significance level $10 \%$ with its p-value is 0.08 , smaller than $\alpha(0.1)$. The score ofregression coefficientis positive with its score 0.071 , it shows that the addition of manure $1 \%$ will increase soybean productivity $0.071 \%$. The average usage of manur in research location is 2.6 ton/ ha. This is in line with research Rahayu (2010) and Sukma, et al (2013).

\section{Gandasil Fertilizer $\left(X_{5}\right)$}

Gandasil fertilizer is for foliar leaves shaped crystals which can support growth of the crop, so it can grow faster and help to form leaves. It is also help generative phase (flowering and fruiting). It can be seen from the content of Nitrogen $(\mathrm{N})$ which is more dominant than elements and other components.

The result of T-statistic in Table 6 show that Gandasil fertilizer is affected significantly towards soybean productivity for significance level $90 \%$ with its p-value 0.06 , smaller than $\alpha(0.1)$. The score of regression coefficient is positive with its score 0.142 , it means that the addition of $1 \%$ Gandasil fertilizer can increase soybean productivity 0.142 . According to Nugroho (2014), efforts to increase soybean plant productivity can be done through leaf. Fertilization through the leaves is done by spraying the fertilizer in liquid form on the plant directly. This method is more effective because it is easy to enter and absorbed into the stomata.

\section{Pesticide $\left(\mathrm{X}_{6}\right)$}

Pesticide is a material use for preventif, controlling, and eradicate a pests. The result of T-test in Table 
6show that pesticide does not effect significantly towards soybean productivity for significance level $99 \%$ and $90 \%$ because of its $p$-value is 0.160 , bigger $\alpha$ (0.1). Pesticide does not effect significantly towards increased soybean productivity but it can prevent or protect the cropsfrom pests and diseases. Factually, the usage of pesticide use to suppress the attack of pests in the field.The right use of pesticide will increase soybean productivity.

\section{Labor $\left(X_{7}\right)$}

Table 6 show that labors do not effect significantly towards soybean productivity for significance leve1 $99 \%$ and $90 \%$ because of its p-value 0.442 , bigger than $\alpha(0.1)$.The Labor is not benchmark for commodity to has a good productivity.

\section{GAP Adoption Rate $\left(X_{8}\right)$}

Good Agriculture Practices (GAP) is a good guideline for cultivation. For soybean, GAP is arrangerd in Permentan No. 48/ Permentan/ OT.140/10/2006 about food cultivation. The result of T-statistic in Table 6 show that GAP adoption level affected significantly towards soybean productivity for significance level $90 \%$ because of its $p$-value 0.08 , smaller $\alpha$ (0.1).The score of regression coefficient is positive with its score is 0.709 , it shows that the addition of GAP adoption levelfor $10 \%$ will increase soybean productivity, assuming the other factors are constant.
The GAP adoption level in Kulon Progo Regency is included as a high category with its adoption level $83.07 \%$. The average of soybeanproductivity in Kulon Progo is 1.2 ton/ ha. These numbers is low enough which the potential of superior varieties can achieve about 2.00 $2.50 \mathrm{ton} / \mathrm{ha}$. It means that the opportunity to increase soybean productivity can be done by maximize a good cultivation process. This is in line with research Setiawan (2015) and Bayramoglu, et al(2010).

\section{CONCLUSION AND SUGGESTION}

GAP adoption level for soybean in Kulon Progo is in high category. The farmers adopt $83.07 \%$ for all components, they are inputs, land preparation, planting, fertilization, plant protection, irrigation, harvest, and post-harvest.

Soybean productivity is affected significantly by factors of seeds, NPK fertilizer, manure, Gandasil fertilizer, and GAP adoption rate. While the land are, pesticides, and labors are not affected significantly toward soybean productivity. The largest of regression coefficient of GAP adoption level affect soybean productivity with its score is 0.709 It shows that each addition of GAP adoption for $1 \%$ can increase soybean productivity $0.709 \%$, assuming other factors are constant.

It is necessary to increase knowledge and understanding of farmers about good 
and proper crop cultivation (GAP) through counseling, training or regular meeting and thorough. In addition, the need for increased application of GAP primarily in the planting process because the early stages greatly affect the growth of soybeans. Planting should be done as recommended by a distance of $40 \times 15 \mathrm{~cm}$ and $40 \times 10 \mathrm{~cm}$, not just following the former planting of rice and use seeds that are certified or labelled to increase productivity and income of soybean farming.

\section{REFERENCES}

Bayramoglu Z, Gundogmus E, Tatlidil FF. 2010. The Impact of EurepGAP Requiement on Farm Income from Greenhouse Tomatoes in Turkey. African Journal of Agricultural ResearchVol. 5 (5), pp. 348-355, 4 March, 2010.

[BPS] Badan Pusat Statistik. 2016. Luas Panen dan Produksi Kedelai Menurut Provinsi (ton), 1993-2015. https:// www.bps.go.id/[Diakses 15 Januari 2017].

Ghozali, I. 2012. Aplikasi Analisis Multivariante Dengan Program SPSS. Semarang: Badan Penerbit Universitas Diponegoro.

Isnowati, S. 2014. Faktor yang mempengaruhi produksi kedelai diDesa Kebonagung, Kecamatan
Tegowanu, Kabupaten Grobogan. SEPA, 10(2): 177-185.

Mahabirama, A.K., Kuswanti, H., Daryanto,S., dan Winandi, R. 2013. AnalisisEfisiensi dan Pendapatan UsahataniKedelai di Kabupaten Garut ProvinsiJawa Barat. Jurnal Aplikasi Manajemen XI(2): 197-206.

Nugroho, N, Bahrun, A. 2014. Pengaruh Sitem Tanam dan Waktu Aplikasi Pupuk Lewat Daun terhadap HAsil Tanaman Kedelai (Glycine max (L.) Merr.) Varietas Anjasmoro Tanpa Olah Tanah. Jurnal Agro UPY Vol. VI. No. 1 September 2014.

Rahayu, W. dan Riptanti, E.W. 2010. Analisis Efisiensi Ekonomi Penggunaan Faktor-Faktor ProduksiPada Usahatani Kedelai Di Kabupaten Sukoharjo. Caraka Tani XXV No. 1 Maret 2010.

Setiawan F, dkk. 2015. Implementasi GAP (Good Agriculture Practice) lada dan pengaruhnya terhadap produktivitas lada di Desa Petaling Banjar, Kecamatan Mendo Barat. Enviagro, Jurnal Pertanian dan Lingkungan. Vol.8 No. 2, hal 72-82. ISSN 1978-1644.

Sukma, T., Hartono, S., Djuwari. 2013. Pattern Alalysis of Tobacco Farming Partnerships and Self in the Lamuk 
Village Tlogomulyo Sub District

Temanggung. Agro Ekonomi Vol. 24/

No. 1, Juni 2013.

Sumarno \& Adie, M.M. 2010. Strategi

Pengembangan Produksi Menuju

Swasembada Kedelai Berkelanjutan.

Jurnal Iptek Tanaman Pangan Vol. 5

No. $1-2010$.

Tahir, AG 2011. Analisis risiko produksi usahatani kedelai pada berbagai tipe lahan di sulawesi selatan. Jurnal Sosial

Ekonomi Pertanian VIII(1): 1-15.

Zakaria, Amar. K. 2010. Kebijakan Pengembangan Budidaya Kedelai Menuju Swasembada melalui Partisipasi Petani. Analisis Kebijakan Pertanian: Volume 8 No. 3. September 2010, P. 259-272. Bogor: Pusat Analisis Sosial Ekonomi dan Kebijakan Pertanian. 